\title{
Penerapan Progressive Web Apps Pada Aplikasi Lowongan Pekerjaan Dosen Universitas Perjuangan
}

\author{
Chan Chan Bayu Bahari', Yusuf Sumaryana \\ ${ }^{1,2,3}$ Teknik Informatika, Fakultas Teknik, Universitas Perjuangan, Jalan PETA No. 177 Kota Tasikmalaya \\ chanbayu@gmail.com¹, yusufsumaryana@unper.ac.id ${ }^{2}$
}

\begin{tabular}{ll}
\hline INFORMASI ARTIKEL & A B S T R A K \\
\hline Sejarah Artikel: & Perkembangan teknologi website terus berkembang dengan cepat, pesat dan tidak bisa di \\
Diterima Redaksi : - & bendung lagi. Salah satu teknologi perkembangan website ialah Progressive Web Apps \\
Revisi Akhir: - & (PWA)). PWA pertama kali diperkenalkan oleh google pada tahun 2015 sebagai salah \\
Diterbitkan Online : - & satu teknologi website modern yang dapat berlaku seperti sebuah mobile application \\
& (aplikasi native). Sekarang ini informasi mengenai lowongan pekerjaan sangatlah \\
Kata Kunci: & dibutuhkan. Banyaknya keinginan untuk menjadi seorang dosen/pengajar di sebuah \\
Progressive Web Apps, Job Vacancy, & Universitas menjadi salah satu contohnya. Universitas yang memiliki banyak Program \\
Service Worker, & Studi namun masih kekurangan tenaga pengajar menjadi salah satu penyebabnya. \\
Waterfall, Laravel & Universitas Perjuangan merupakan salah satu Universitas yang bertempat di kota \\
& Tasikmalaya yang berada di bawah naungan Yayasan Universitas Siliwangi. Penelitian \\
Korespondensi : & ini berfokus pada penyajian informasi lowongan pekerjaan dan menampung data \\
Telepon / Hp : +62 85316608606 & pendaftaran dosen Universitas Perjuangan Pada penelitian ini peneliti menggunakan \\
E-mail : yusufsumaryana@unper.ac.id & teknologi Progressive Web Apps (PWA) dan menggunakan framework laravel. Metode \\
& pengembangan yang digunakan untuk aplikasi lowongan pekerjaan dosen Universitas \\
& $\begin{array}{l}\text { Perjuangan adalah metode waterfall. metode waterfall memiliki tahapan yang dimulai } \\
\text { dari requirement definition, system and software design, implementation and unit testing, }\end{array}$ \\
& integration and system testing dan operation and maintenance.
\end{tabular}

\section{PENDAHULUAN}

PWA pertama kali diperkenalkan oleh google pada tahun 2015 sebagai salah satu teknologi website modern yang dapat berlaku seperti sebuah mobile application (aplikasi native). Menurut Techopedia (Santoso, 2019) Aplikasi native adalah aplikasi smartphone yang dibuat dalam bahasa pemograman tertentu, seperti Swift dan Objective $C$ untuk IOS (Apple), Java untuk Android atau .NET untuk platform Windows.

Di era sekarang ini informasi mengenai lowongan pekerjaan sangatlah dibutuhkan. Banyaknya keinginan untuk menjadi seorang dosen/pengajar di sebuah Universitas menjadi salah satu contohnya. Universitas yang memiliki banyak Program Studi namun masih kekurangan tenaga pengajar menjadi salah satu penyebabnya contohnya di Universitas Perjuangan Kota Tasikmalaya. Universitas Perjuangan sudah baik dalam memanfaatkan teknologi, namun belum adanya menu lowongan pekerjaan dosen sehingga kurang memudahkan orang untuk menemukan lowongan pekerjaan online menggunakan website/aplikasi di Universitas tersebut, sedangkan Universitas Perjuangan masih membutuhkan tenaga kerja sebagai dosen.

Berdasarkan penelitian sebelumnya yang dilakukan oleh Afif Rizki Kurniawan (2018) dalam skripsinya yang berjudul "Penerapan Progressive Web Apps Pada Aplikasi Lowongan Pekerjaan Dengan Teknologi Service Worker (Studi Kasus Akakom Carrer Center)" menyatakan bahwa "Progressive Web Apps $(P W A)$ adalaah aplikasi native yang mendukung hybrid secara penuh dan apklikasi ini tidak perlu proses penginstallan terlebih dahulu namun langsung dapat digunakan secara penuh". Namun masih terdapat kekurangan pada penelitian ini yaitu tidak dapat menggambil file berektensi php, sehingga hasil pembuatan nya masih berektensi html.

\section{LANDASAN TEORI}

\subsection{Progressive Web Apps (PWA)}

Progressive Web Apps (PWA) Santoso (2019) menyatakan bahwa "Progressive Web Apps merupakan teknologi sebuah website yang dibangun menggunakan teknologi web modern, namun dapat berlaku seperti sebuah mobile app". Kemunculan PWA membawa pengaruh positif pada pengembangan aplikasi web. Aplikasi PWA tidak dikemas (packaged) dan disebarkan (deployed) melalui toko aplikasi, melainkan sebuah aplikasi web yang di share melalui link website yang dapat ditambahkan ke Home Screen. Teknologi yang umum digunakan pada PWA meliputi Web App Manifest, Service Worker, App Shell yang semuanya memerlukan web browser terbaru.

Kurniawan, dkk. (2017) menyatakan bahwa "Progressive Web Apps (PWA) adalah sebuah istilah untuk aplikasi berbasis web yang menggunakan teknologi web paling mutakhir. PWA sebenarnya hanyalah aplikasi berbasis web biasa, tapi memanfaatkan fitur perambanan yang modern agar tampil seolah-olah merupakan aplikasi asli”.

Kurniawan (2018) dalam penelitian nya menjelaskan bahwa "Progressive Web Apps adalah aplikasi native yang mendukung hybrid secara penuh dan aplikasi ini tidak perlu proses penginstallan terlebih dahulu namun langsung dapat digunakan secara penuh". 
Program PWA memiliki banyak kelebihan yang akan memudahkan penggunan dalam menyelami sebuah website secara penuh. Apabila dibandingkan dengan hybrid, PWA ini penengah antara native dan hybrid sehingga kondisinya akan lebih stabil namun tetap up to date sesuai kondisi hybrid yang sebenarnya.

Berdasarkan uraian diatas Progressive Web Apps (PWA) adalah teknologi website modern yang menyerupai aplikasi native (mobile app) dan mendukung hybrid secara penuh. Kemudahan dalam penggunaan serta tampilan yang responsive menjadi fitur unggulan dari PWA. Teknologi PWA masih tergolong teknologi baru, sehingga masih banyak orang yang belum mengetahuinya. Kelebihan dari PWA :

1. Layout Responsive

Teknologi PWA memiliki kelebihan yaitu layout responsive yaitu dimana tampilan website bisa menyesuaikan jika diakses dengan perangkat apapun.

2. Add To Home Screen

Dengan fitur ini lah yang membuat PWA memiliki kemampuan seperti aplikasi native. Fitur ini digunakan untuk mempermudah pengguna website tanpa harus menuliskan URL nya kembali di browser.

3. Instan Loading

Dengan adanya service worker, waktu memuat halaman web akan menjadi lebih cepat walaupun dengan keadan offline atau konektivitas yang tidak stabil.

\subsection{Service Worker}

Santoso (2019) menyatakan bahwa "Service Worker adalah salah satu jenis Web Worker, JavaScript yang berjalan di background tanpa mempengaruhi kinerja halaman web". Service Worker pada dasarnya adalah file JavaScript yang berjalan di client side secara terpisah dari rangkaian browser utama, berfungsi mencegat permintaan jaringan, melakukan cache atau mengambil sumber daya dari cache, dan mengirimkan pesan. Kurniawan, dkk. (2017) dalam penelitiannya menyatakan "Service worker adalah script yang berjalan di belakang browser pengguna". Service worker tidak membutuhkan sebuah halaman ataupun interaksi dari pengguna untuk menjalankan tugasnya, dengan begitu service worker akan terus berjalan walaupun halaman web tidak terbuka.

Berdasarkan uraian di atas Service Worker adalah sebuah plugins (script) yang berfungsi untuk mendapatkan fitur offline mode, sehingga dapat memudahkan pengguna untuk bisa mengakses website walau dalam keadaan koneksi tidak stabil.

\section{METODOLOGI}

\subsection{Metode Pengumpulan data}

Pengumpulan data Tugas Akhir ini menggunakan beberapa metode yang dapat mendukung penulis baik dalam pengumpulan data maupun informasi yang diperlukan untuk mendapatkan kebenaran materi uraian pembahasan. Adapun metode pengumpulan data yang digunakan dalam pembahasan Tugas Akhir ini adalah menggunakan metode observasi, metode wawancara, dan metode studi kepustakaan.

\subsubsection{Metode Observasi}

Metode observasi dilakukan dengan cara pengamatan dan pengumpulan data yang dibutuhkan dalam perancangan yang diambil dari tempat penelitian.

\subsubsection{Metode Wawancara}

Penelitian dengan mengadakan sesi wawancara atau tanya jawab dengan pihak intansi atau pihak terkait untuk mendapatkan informasi yang dibutuhkan yang berhubungan dengan masalah penelitian.

\subsubsection{Metode Studi Kepustakaan}

Mengumpulkan data data yang dilakukan dengan cara membaca buku atau mencari jurnal di internet yang berkaitan dengan permasalahan.

\subsection{Lokasi Penelitian}

Penelitian ini dilakukan di kampus Universitas Perjuangan Tasikmalaya. Penelitian ini adalah penelitian dengan membuat aplikasi lowongan pekerjaan dosen Universitas Perjuangan Waktu penelitian diperkirakan berlangsung selama 6 (enam) bulan yang dimulai dari perencanaan, pembuatan aplikasi, pengujian serta pengambilan data.

\subsection{Instrumen Penelitian \\ 3.3.1. Perangkat Keras}

Perangkat keras yang digunakan untuk mengembangkan dan pengumpulan data dalam penelitian ini. Laptop mempunyai spesifikasi sebagai berikut :

1. Processor Intel Core i3 5005U @2.00GHz

2. Ram DDR3L 8GB

3. HDD $500 \mathrm{~GB}$

\subsubsection{Perangkat Lunak} berikut :

Adapun perangkat lunak yang digunakan sebagai

1) Browser Google Chrome

2) Text editor Sublime

3) Xampp 3.2.2

4) Windows 10 Pro 64-Bit

\subsection{Metodelogi Pengembangan Perangkat Lunak}

Metode yang digunakan dalam tahap pengembangan aplikasi lowongan pekerjaan dosen Universitas Perjuangan ini adalah metode (waterfall). Metode Waterfall merupakan contoh dari tahapan yang plan-driven, yaitu secara prinsip pengembang harus merencanakan dan menjadwalkan semua kegiatan tahapan sebelum mulai mengembangkan perangkat lunak. Komitmen dibuat di awal tahapan sehingga membuat sulit untuk merespon ketika ada perubahan pada kebutuhan customer (Sommerville, 2011). Metode waterfall bertujuan untuk menghasilkan perangkat lunak yang berkualitas tinggi. Dalam pengembangan 
metode waterfall menurut Sommerville (2011) memiliki berbagai tahapan yang berurut yaitu, requirement definition, system and software design, implementation and unit testing, integration and system testing dan operation and maintenance. Tahapan waterfall ditunjukan pada Gambar 3.1.

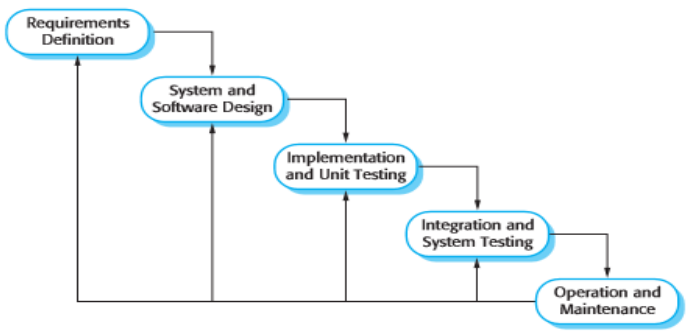

Sumber Sommerville, I. (2011).

Gambar 3.1 Tahap-tahap metode waterfall

\section{HASIL DAN PEMBAHASAN}

\subsection{Prosedur Usulan Sistem}

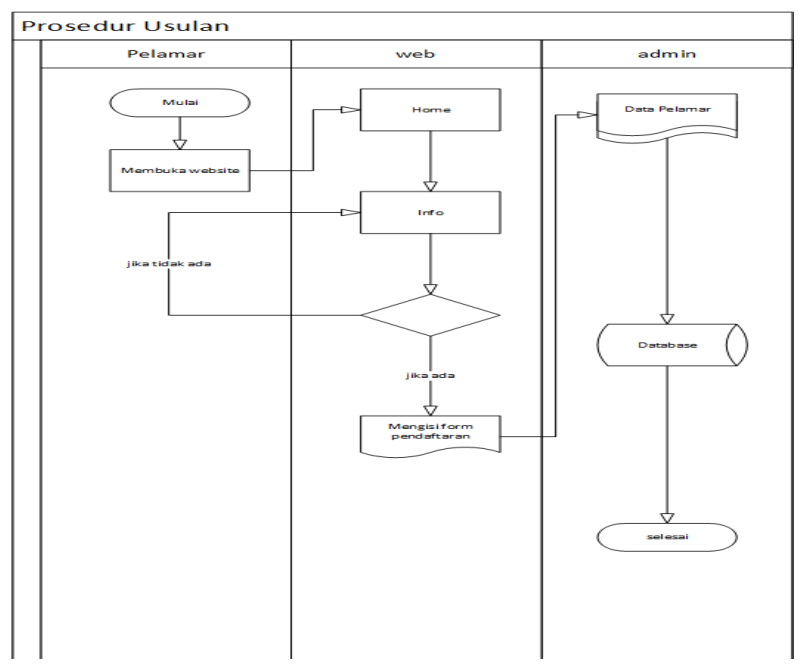

Gambar 3.1 Prosedur Usulan Sistem

Hal yang dilakukan pertama kali oleh pelamar adalah mengakses website atau aplikasi lowongan pekerjaan yang sudah disediakan, kemudian dalam web tersebut terdapat beberapa menu salah satunya yaitu menu home. Di dalam menu home terdapat menu info. Menu info akan menampilkan tersedia atau tidaknya lowongan pekerjaan untuk dosen di Universitas Perjuangan Kota Tasikmalaya. Jika pada menu info tersedia lowongan pekerjaan bagi dosen maka pelamar bisa melakukan pendaftaran dengan cara mengklik menu daftar kemudian pelamar bisa langsung melakukan pendaftaran dengan mengisi form pendaftaran yang sudah disediakan. Pendaftaran tersebut akan diterima oleh admin website tersebut kemudian data tersebut disimpan di database. Keunggulan dari website ini adalah memudahkan pencari pekerjaan khususnya bagi dosen di Universitas Perjuangan, dan pendaftaran dapat dilakukan dengan mudah dan efisien.

\subsection{Perancangan Antar Muka}

4.2.1 Rancangan Halaman Home

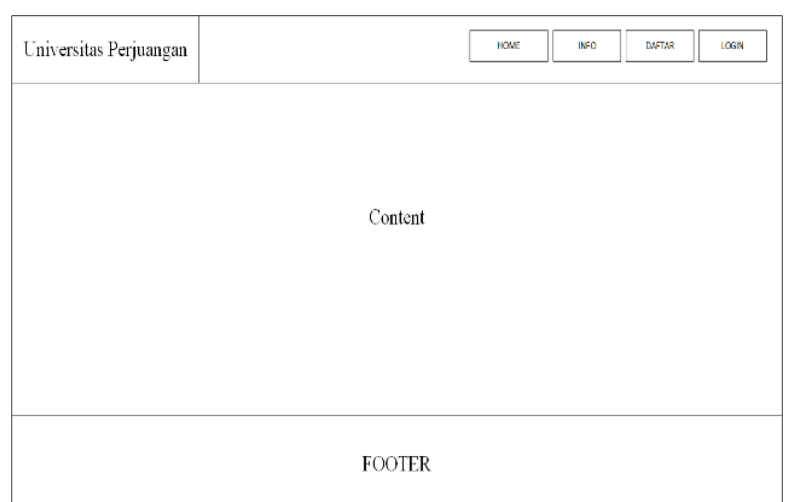

Gambar 3.2 Rancangan Halaman Home

Halaman ini adalah halaman yang pertama kali di akses oleh pengunjung. Jika menekan menu home maka akan memunculkan halaman ini. Jika menekan menu info makan akan muncul tampilan info, jika menekan menu daftar maka akan menuju halaman pendaftaran.

\subsubsection{Rancangan Tampilan Halaman Daftar}

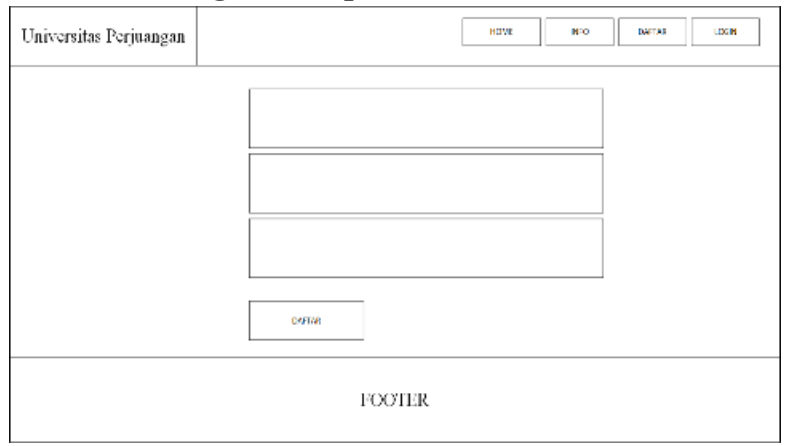

Gambar 3.3 Rancangan Tampilan Halaman Daftar

Jika pengisian form pendaftaran lengkap dan mengklik tombol daftar maka akan muncul notifikasi berhasil mendaftar.

\subsubsection{Rancangan Form Login}

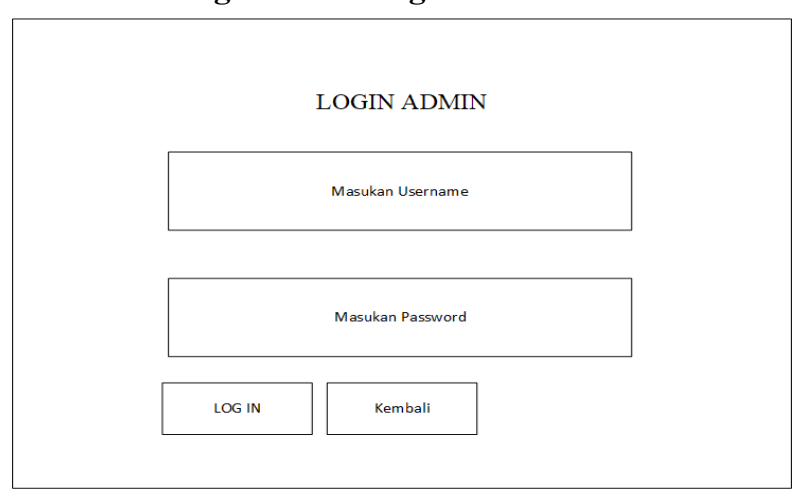

Gambar 3.4 Rancangan Form Login 


\subsection{Analisis Sistem}

Analisis Sistem adalah suatu sistem informasi yang utuh kemudian di uraikan kedalam bagian-bagian komponen dengan tujuan untuk mengidentifikasi permasalahan, kesempatan, hambatan, yang terjadi kemudian dilakukan evaluasi sehingga kebutuhankebutuhan yang menjadi suatu harapan atau keinginan dapat diusulkan menjadi sebuah perbaikan.

\subsubsection{Prosedur Yang Sedang berjalan}

Prosedur yang sedang berjalan di Universitas Perjuangan di gambarkan sebagai berikut :

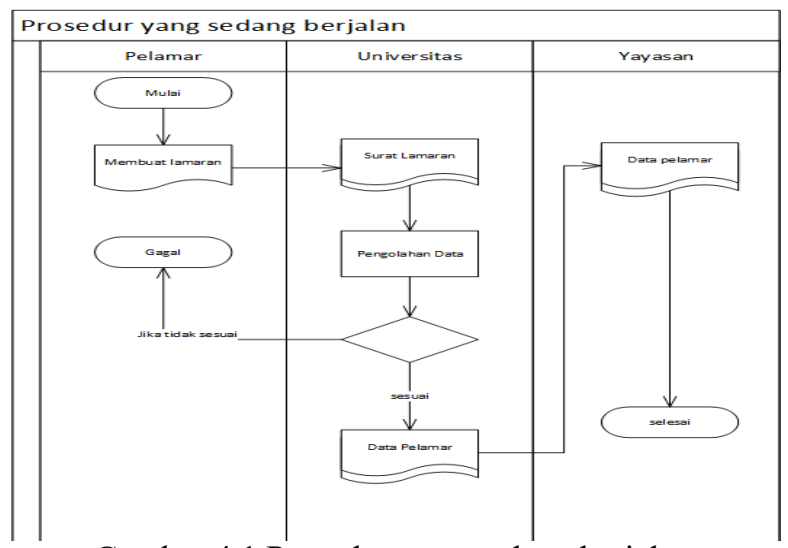

Gambar 4.1 Prosedur yang sedang berjalan

Prosedur yang sedang berjalan dijelaskan bahwa lowongan pekerjaan untuk dosen Universitas Perjuangan sudah menggunakan teknologi masa kini yaitu dengan penggunaan e-mail (elektronik mail) bagi calon pelamar. Calon pelamar membuat lamaran dalam word kemudian mengirim surat yang ditujukan pada rektor, lamaran tersebut dikirim melalui email Universitas Perjuangan, data tersebut diterima oleh administrasi umum setelah itu dikirimkan ke bagian staff kepegawaian dan dilakukan pengolahan data dengan kriteria yang sudah sesuai ketentuan, setelah melakukan penyaringan atau pengolahan data pelamar yang sesuai dengan kriteria kemudian diajukanlah lamaran tersebut kepada yayasan Universitas Perjuangan dan jika data pelamar tidak sesuai dengan kriteria tersebut maka di anggap gagal. Berdasarkan temuan yang dilakukan peneliti cara yang dilakukan ini masih dikatakan manual karena Universitas Perjuangan belum memiliki aplikasi khusus bagi pelamar sebagai dosen, padahal aplikasi khusus untuk lowongan pekerjaan di sebuah Universitas sangat dibutuhkan agar memudahkan pelamar untuk mengakses apa yang mereka butuhkan dan memudahkan Universitas menyaring dan merkrut pelamar yang sesuai dengan kriteria yang dibutuhkan dan diharapkan bagi kemajuan Universitas itu sendiri.

\subsubsection{Metode Perangcangan Sistem}

Metode perancangan aplikasi lowongan pekerjaan dosen Universitas Perjuangan menggunakan metode terstuktur dengan alat bantu perancangan aplikasi yaitu Unified Modeling Language(UML).
Setelah melakukan analisa terhadap kondisi pelayanan yang berjalan di Universitas Perjuangan, penulis mulai merancang aplikasi atau website yang bertujuan untuk menampung informasi dan sarana umpan balik antara pihak intansi dan para pencari kerja. Perancangan aplikasi atau website ini dengan menggunakan Unified Modeling Language (UML) sebagai bahasa pemodelan sebagai berikut :

\section{Use Case Diagram}

Use case diagram merupakan pemodelan yang menggambarkan interaksi antara pengguna dengan sistem. Adapun hubungan relasi pada aplikasi lowongan pekerjaaan dosen Universitas Perjuangan dapat dilihat pada gambar dibawah ini.

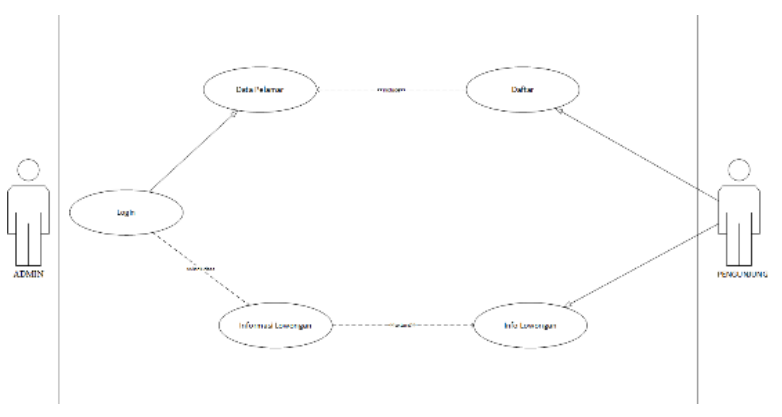

Gambar 4.3 Use Case Diagram aplikasi lowongan pekerjaan dosen

\section{Activity Diagram}

Activity Diagram atau diagram aktivitas merupakan gambaran dari proses kerja sistem yang berisi aktivitas aktivitas dari titik awal sampai titik berakhir.

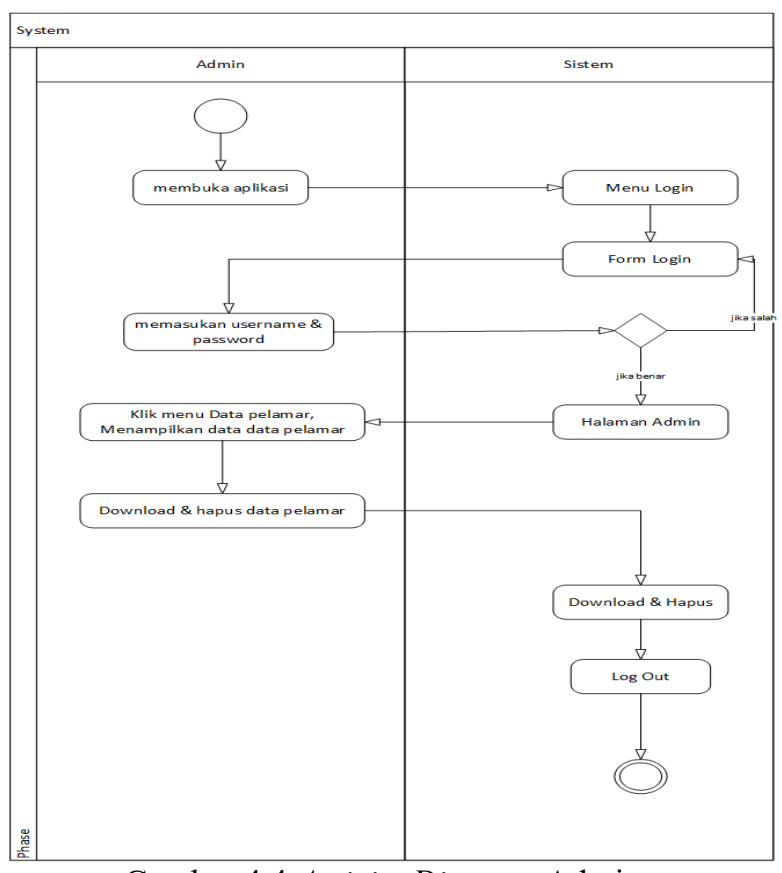

Gambar 4.4 Activity Diagram Admin 
3. Activity Diagram

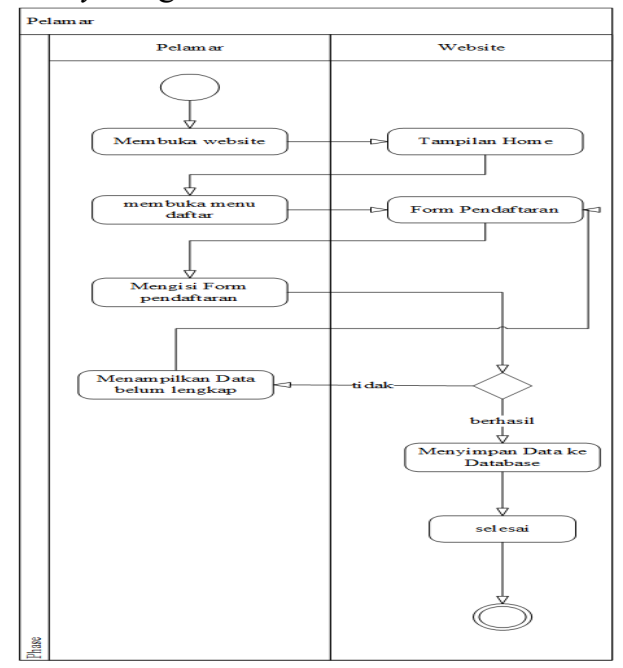

Gambar 4.5 Activity Diagram Pelamar

4. Activity Diagram

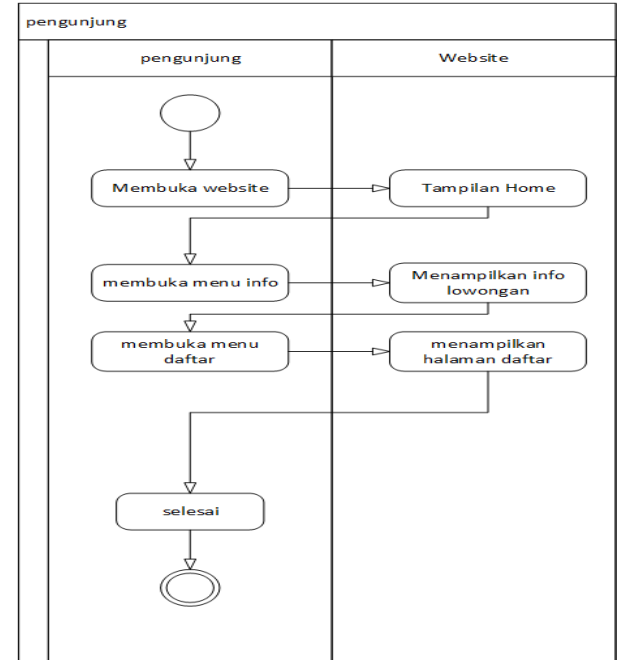

Gambar 4.6 Activity Diagram Pengunjung

5. Class Diagram

Class Diagram adalah diagram UML yang menggambarkan stuktur database dari suatu sistem dengan menunjukan sistem kelas, attribut dan hubungan satu dengan lainya.

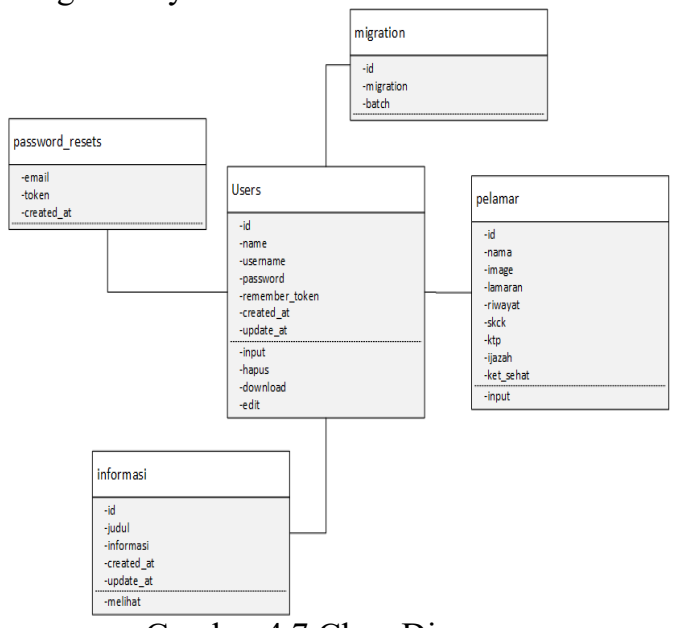

Gambar 4.7 Class Diagram

\section{Sequence Diagram}

Sequence Diagram adalah diagram UML yang menggambarkan interaksi beberapa objek yang saling berkaitan dalam urutan waktu.

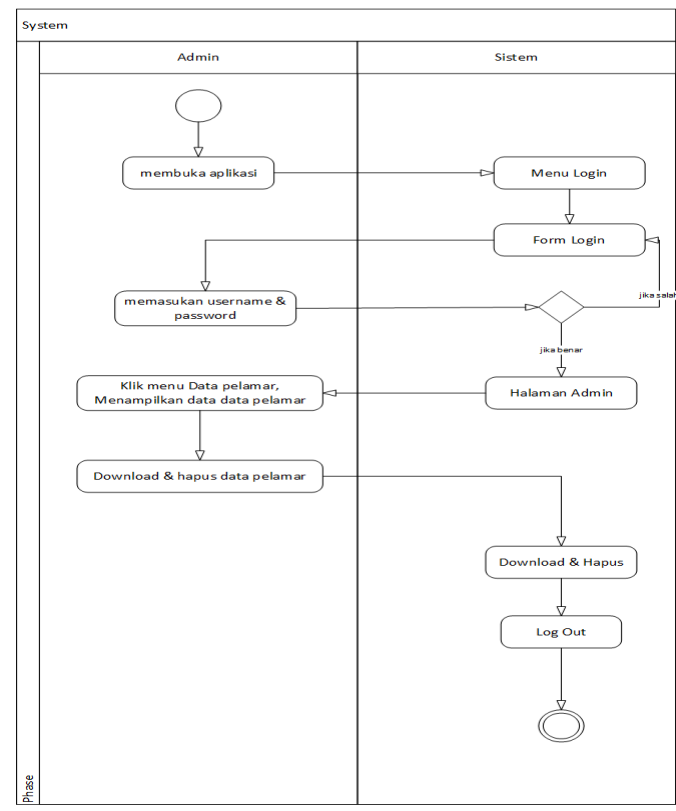

Gambar 4.8 Squence Diagram

7. Squence Diagram Admin

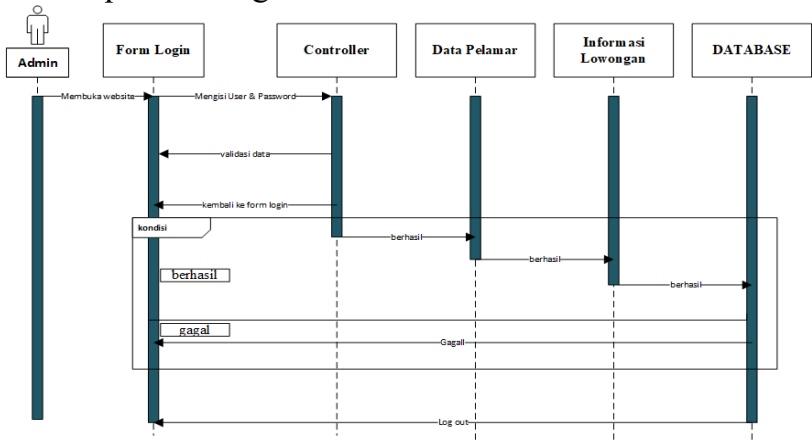

Gambar 4.8 Squence Diagram Admin

8. Squence Diagram Pengunjung

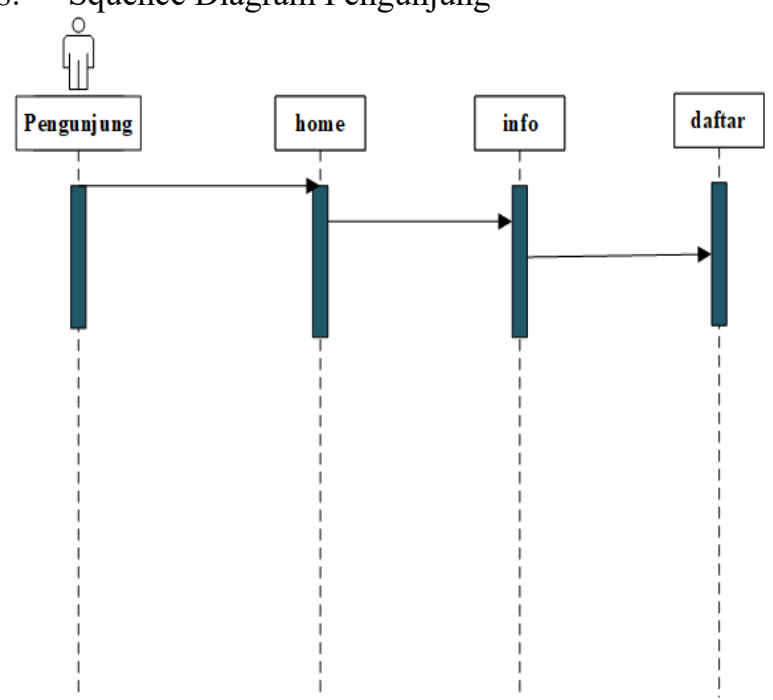

Gambar 4.9 Squence Diagram Pengunjung 
9. Squence Diagram Pelamar

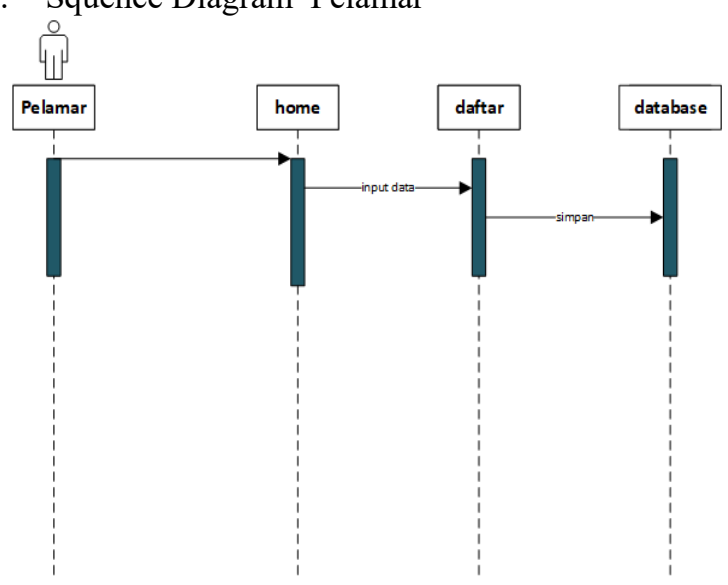

Gambar 4.10 Squence Diagram Pelamar

\subsection{Perancangan Basis Data}

Perancangan skema database pada aplikasi lowongan pekerjaan dosen Universitas Perjuangan ini di dasarkan pada desain Class Diagram yang ada.

Berdasarkan fitur serta tabel dan atribut yang nantinya digunakan sebagai data storage aplikasi tersebut.

1. Data Dictionary (Kamus Data)

a. Users : id, name, username, password, remember_token.

b. Pelamar : id, nama, image, lamaran, riwayat, skck, ktp, ijazah, ket_sehat, created_at, update_at.

c. Informasi : id, judul, informasi, created_at, update_at

d. Password_resets : email, token, created_at.

e. Migration : id, migration, batch.

\section{Data Object Description (DOD)}

Tabel 4.1 Stuktur Tabel Users

\begin{tabular}{|c|c|c|c|}
\hline \multicolumn{4}{|c|}{$\begin{array}{l}\text { Nama Tabel : users } \\
\text { Primary Key : id } \\
\text { Foreign Key : - }\end{array}$} \\
\hline No & Nama & Tipe & Keterangan \\
\hline 1. & Id & integer & Primary Key \\
\hline 2. & Name & varchar & \\
\hline 3. & Username & varchar & \\
\hline 4. & Password & varchar & \\
\hline 5. & Remember token & varchar & \\
\hline
\end{tabular}

Tabel 4.2 Stuktur Tabel Pelamar

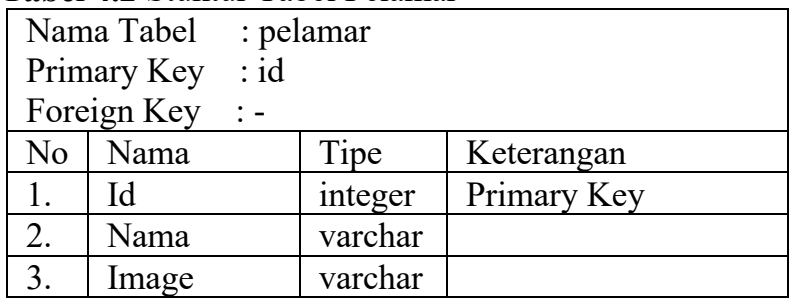

\begin{tabular}{|l|l|l|l|}
\hline 4. & Lamaran & varchar & \\
\hline 5. & Riwayat & varchar & \\
\hline 6. & Skck & varchar & \\
\hline 7. & Ktp & varchar & \\
\hline 8. & Ijazah & varchar & \\
\hline 9. & Ket_Sehat & varchar & \\
\hline 10. & Created at & varchar & \\
\hline 11. & Updated at & varchar & \\
\hline
\end{tabular}

Tabel 4.3 Struktur Tabel Informasi

\begin{tabular}{|c|c|c|c|}
\hline $\begin{array}{l}\text { Nan } \\
\text { Prin } \\
\text { For }\end{array}$ & $\begin{array}{ll}\text { la Tabel } & \text { : } \\
\text { lary Key } & : \text { i } \\
\text { ign Key } & :-\end{array}$ & formasi & \\
\hline No & Nama & Tipe & Keterangan \\
\hline 1. & Id & integer & Primary Key \\
\hline 2. & Judul & varchar & \\
\hline 3. & Informasi & varchar & \\
\hline 4. & Created_at & varchar & \\
\hline 5. & Updated_at & varchar & \\
\hline
\end{tabular}

\subsection{Implementasi Sistem}

Tahapan Implementasi sistem merupakan tahap perubahan sistem yang telah dirancang sebelumnya menjadi sistem yang bisa di jalankan di berbagai platform atau perangkat keras.

\subsubsection{Tampilan Halaman Home}

Halaman ini merupakan halaman yang pertama kali di tampilkan saat membuka website atau aplikasi di web browser ataupun di smartphone. Tampilan ini berisi menu menu yang ada pada website.

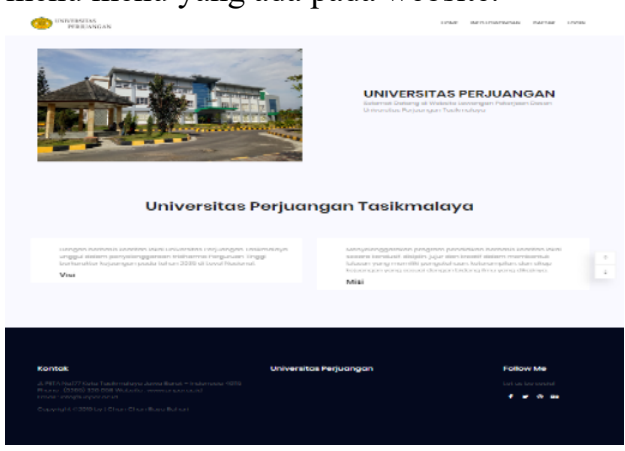

Gambar 4.17 Tampilan Halaman Home

\subsubsection{Tampilan Halaman Info Lowongan}

Tampilan halaman ini berisi informasi mengenai lowongan pekerjaan dosen Universitas Perjuangan.

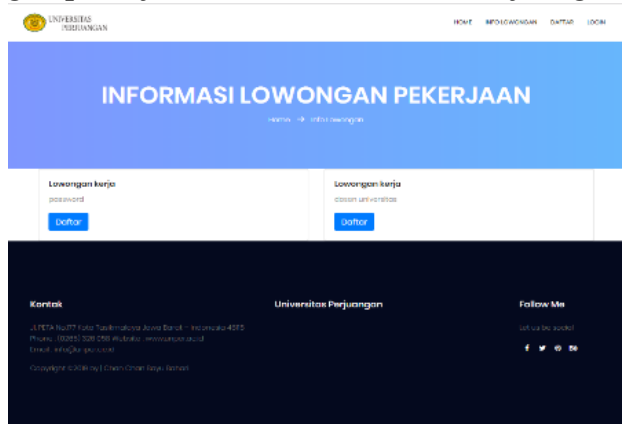

Gambar 4.18 Tampilan Halaman Info Lowongan 


\subsubsection{Tampilan Halaman Daftar}

Tampilan halaman ini berisi form pendaftaran yang digunakan untuk melakukan pendaftaran.

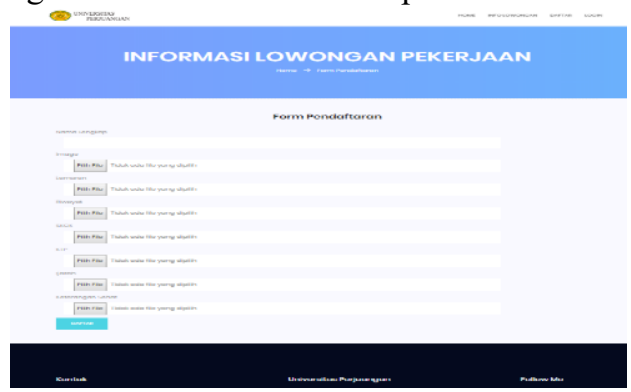

Gambar 4.19 Tampilan Form Pendaftaran

Adapun keunggulan dari aplikasi lowongan pekerjaan dosen universitas perjuangan adalah sebagai berikut:

1. Dapat di akses melalui smartphone ataupun komputer .

2. Tampilan yang responsive sehingga dapat menyesuaikan tampilan versi mobile dan desktop.

3. Dengan menggunakan fitur add to home screen pengguna dapat menambahakan atau menginstal aplikasi atau website tersebut.

4. Dapat di akses dengan koneksi tidak stabil ataupun offline.

\section{KESIMPULAN}

Berdasarkan pembahasan pada bab-bab sebelumnya dapat disimpulkan dalam penelitian Tugas Akhir ini adalah sebagai berikut :

1. Tujuan penelitian ini sudah tercapai yaitu menerapkan teknologi Progressive Web Apps pada aplikasi lowongan pekerjaan dosen Universitas Perjuangan dengan menggunakan framework laravel. Adapun hasil pengujian dengan menggunakan black box sudah sesuai dengan yang diharapkan.

2. Penerapan sistem ini menggunakan teknologi service worker sehingga dapat diakses dalam keadaan koneksi internet tidak stabil maupun offline.

Aplikasi/Website ini dapat memudahkan para pencari pekerjaan, khususnya dosen di universitas Perjuangan.

\section{DAFTAR PUSTAKA}

Abdulloh, R. (2016). Easy \& Simple Web Programming. Jakarta: PT Elex Media Komputindo, 227.

Kurniawan, A., Areni, I. S., \& Achmad, A. (2017). Implementasi Progressive Web Application pada Sistem Monitoring Keluhan Sampah Kota Makassar. Jurnal JPE, 21(02), 34-38.

Kurniawan, A.R. (2018). (SKRIPSI) "Penerapan Progressive Web Apps Pada Aplikasi Lowongan Pekerjaan dengan Teknologi Service Worker (Studi Kasus Akakom Carrer Center )" Teknik Informatika. Sekolah Tinggi Manajemen Informatika dan Komputer Akakom YOGYAKARTA.
Sari, N. P., Kurniadi, D., \& Irfan, D. (2018). Sistem Informasi Reservasi Fasilitas Universitas Negeri Padang Berbasis Framework Laravel. Jurnal Vokasional Teknik Elektronika Dan Informatika, $6(2)$.

Santoso, Hendra. (2019). Membangun Aplikasi Mobile dengan PROGRESSIVE WEB APP (PWA). Yogyakarta: Lokomedia

Wibowo, granodio. (2017). Perancangan Kuisioner Evaluasi Berbasis Mobile Web Application Menggunakan PWA. (Skripsi). Teknik Informatika, Universitas Muhammadiyah. Malang 